TUFfery, A. A. (1954). J. gen. Microbiol. 10, 342-344,

\title{
The Nuclear Structures of Oscillospira guilliermondi Ghatton and Perard
}

\author{
By A. A. TUFFERY \\ Department of Bacteriology, University of Birmingham
}

SUMMARY : Cytological studies of Oscillospira guilliermondi from the caecal contents of guinea-pigs show that this organism consists of trichomes with numerous disklike cells containing nuclei in the form of paired rods. They offer a peculiarly clear illustration of this typically eubacterial form of nucleus.

Oscillospira guilliermondi is a relatively large multicellular micro-organism first described by Chatton \& Perard (1913) in the caecal contents of the guineapig. These workers were unable to demonstrate any nuclear structures, and for this reason they considered it to be a member of the Myxophyceae, with which classification many subsequent workers have concurred. Baker (1933, 1943) found $O$. guilliermondi in ox rumen and in guinea-pig caecum, and was similarly unable to show nuclear structures of any kind, although Simons (1922), working with guinea-pig material, described a series of nuclear changes preceding spore formation which Delaporte (1934) confirmed. Moir \& Masson (1952) described a similar organism from the rumen of sheep, and were of the opinion that it was divided into a number of segments, each of which contained one nucleus. Although a nucleus is now accepted as being present in this interesting organism, little real detail concerning its structure has so far been produced; the observations presented here suggest that it is eubacterial rather than algal in character.

Robinow (1942) used the acid-Giemsa technique for the first convincing demonstration of bacterial nuclear structures, which he and subsequent workers have shown, in the vegetative stages, to consist of paired rod-like bodies (Robinow, 1945; Bisset, 1950). By the use of this method, an exceedingly clear demonstration of a nucleus of this type in $O$. guilliermondi can be achieved.

\section{MATERIALS AND METHODS}

As $O$. guilliermondi has yet to be grown in pure culture, its cytology was studied in preparations made from guinea-pig caecal contents in which it occurs very frequently. Thin films were made on cover-slips and stained without fixation, by the acid-Giemsa technique as described by Bisset (1950). Hydrolysis in $\mathrm{N}-\mathrm{HCl}$ for 13 min., and staining in dilute Giemsa for 3-4 min., gave very good results.

\section{OBSERVATIONS}

Mature individuals of 0 . guilliermondi measured 5-7 $\mu$. in width, and from 20 to $70 \mu$. in length, and consisted of a trichome of narrow disk-like cells. Each cell contained a nucleus in the form of two rod-like bodies, parallel to each other and at right-angles to the long axis of the trichome. The paired nature of the nucleus is seen particularly well in Pl. 1, figs. 1, 2. The nuclei in any one trichome did not all lie in the same plane, and the paired rods presented 
all aspects from profile to end-on. The individual organism in Pl. 1, fig. 1, shows the nuclear rods of five adjacent cells lying in planes which are alternately at right-angles. As may be expected of rod-like structures, those seen in profile appear less intensely light-absorbent than those seen from the end, since a greater depth of stained material is presented in the latter case. This interpretation of their form appears more probable, therefore, than the alternatives that they represent rods or disks of varying length or diameter, as their intensity would then be either indifferent or greater in the larger (profile) examples, rather than in the smaller (end-on) examples.

It is not clear from the brief description of Moir \& Masson (1952) exactly what they consider to constitute a single cell. Presumably an entire individual is implied, whereas it is obvious from the photomicrographs shown here that each organism consists of from ten to thirty or more cells. The transverse septa, stained by Giemsa, are clearly seen between each nucleus in Pl. 1, figs. 1, 3 and 4. Fully formed cross walls, appearing as unstained gaps in the length of the organism, can be seen in Pl. 1, fig. 2 .

Most authors are agreed that $\boldsymbol{O}$. guilliermondi forms endospores in a manner typical of Eubacteria. Delaporte (1934) described the full cycle of events in the process, which she claimed to be comparable with that occurring in spore-forming bacteria. Her account is based on iron-haemotoxylin stained preparations which are less clear and less easily interpreted than is the acidGiemsa stained material presented here. Even from these, a complete understanding of the process cannot yet be obtained, but it appears that the nuclei at points $a, b$ and $c$ (Pl. 1, figs. 3,4) are in various stages of condensation preliminary to spore maturation. It is probable that $a$ represents the most, and $c$ the least, advanced stages.

\section{DISCUSSION}

Chatton \& Perard (1913), Simons (1922), and Baker (1943) accepted $O$. guilliermondi as a member of the Myxophyceae, whereas Fritsch (1945) doubts the validity of such a grouping on the grounds that its mode of spore formation is not typical of the class. Moir \& Masson (1952), following Peshkoff in the 6th edition of Bergey's Manual (1948), placed it with the true bacteria; so also did Pringsheim (1949), who stated that Robinow had demonstrated the possession of peritrichous flagella by $O$. guilliermondi. To this bacterial character is now added that of the possession of typically bacterial nuclei in the form of paired transverse rods. $O$. guilliermondi thus affords a very good example of a typical bacterial nucleus, and because of its size permits this structure to be more accurately observed than in smaller genera, and shows that the vegetative nucleus consists of paired rods, which can be observed in various aspects, and not of disks as has been occasionally suggested. It also shows the advanced degree of multicellular structure which can be observed in some micro-organisms. Although considerably larger, O. guilliermondi closely resembles Caryophanon spp. both in morphology and habitat, and may reasonably be presumed to belong also to the Order Eubacteriales, as defined by Bisset \& Moore (1950). 


\section{REFERENCES}

BAKER, F. (1933). Studies in the microbiology of organisms associated with the disintegration of vegetable remains. Zbl. Bakt. (2. Abt.), 88, 17.

BAKER, F. (1943). Direct microscopical observations on the rumen population of the ox. Ann. appl. Biol. 30, 230.

Bergey's Manual of Determinative Bacteriology (1948). 6th ed. Edited by BreEd, R. S., Murray, E. G. D. \& Hitchens, A. P. London: Baillière, Tindall and Cox.

Bisset, K. A. (1950). The Cytology and Life-History of Bacteria. Edinburgh: E. and S. Livingstone, Ltd.

Bisset, K. A. \& Moone, F. W. (1952). Bacteria. Edinburgh: E. and S. Livingstone, Ltd.

Chatton, E. \& Perard, C. (1913). Schizophytes du caecum du cobaye. I. Oscillospira guilliermondi n.g., n.sp. C.R. Soc. Biol., Paris, 74, 1159.

Delaporte, B. (1934). Sur la structure et le procédé de sporulation de l'Oscillospira guilliermondi. C.R. Acad. Sci., Paris, 198, 1187.

Fritsch, F. E. (1945). The Structure and Reproduction of the Algae. Vol. II. Cambridge University Press.

Moir, R. J. \& Masson, M. J. (1952). An illustrated scheme for the microscopic identification of the rumen micro-organisms of sheep. J. Path. Bact. 64, 343.

Pringsheim, E. G. (1949). The relationship between bacteria and myxophyceae. Bact. Rev. 13, 47 .

Robinow, C. F. (1942). A study of the nuclear apparatus of bacteria. Proc. roy. Soc. B, 139, 299.

Roвinow, C. F. (1945). Addendum to The Bacterial Cell, by Dubos, R. J. Harvard University Press.

Srmons, H. (1922). Saprophytische Oscillatorien des Menschen und der Tiere. Z Zbl. Bakt. (1. Abt. Orig.), 88, 501.

\section{EXPLANATION OF PLATE}

Fig. 1. Oscillospira guilliermondi; each cell contains one nucleus, consisting of a pair of rodlike bodies. Acid-Giemsa, $\times 1000$.

Fig. 2. O. guilliermondi; nuclei. Mature cross walls can be seen as unstained gaps in the length of the trichome. Acid-Giemsa, $\times 1000$.

Figs. 3, 4. O. guilliermondi; nuclei. Nuclear condensation preliminary to spore formation can be seen at points $a, b$ and $c$. Acid-Giemsa. $\times 1000$.

(Received 10 November 1953) 
Journal of General Microbiology, Vol. 10, No. 2
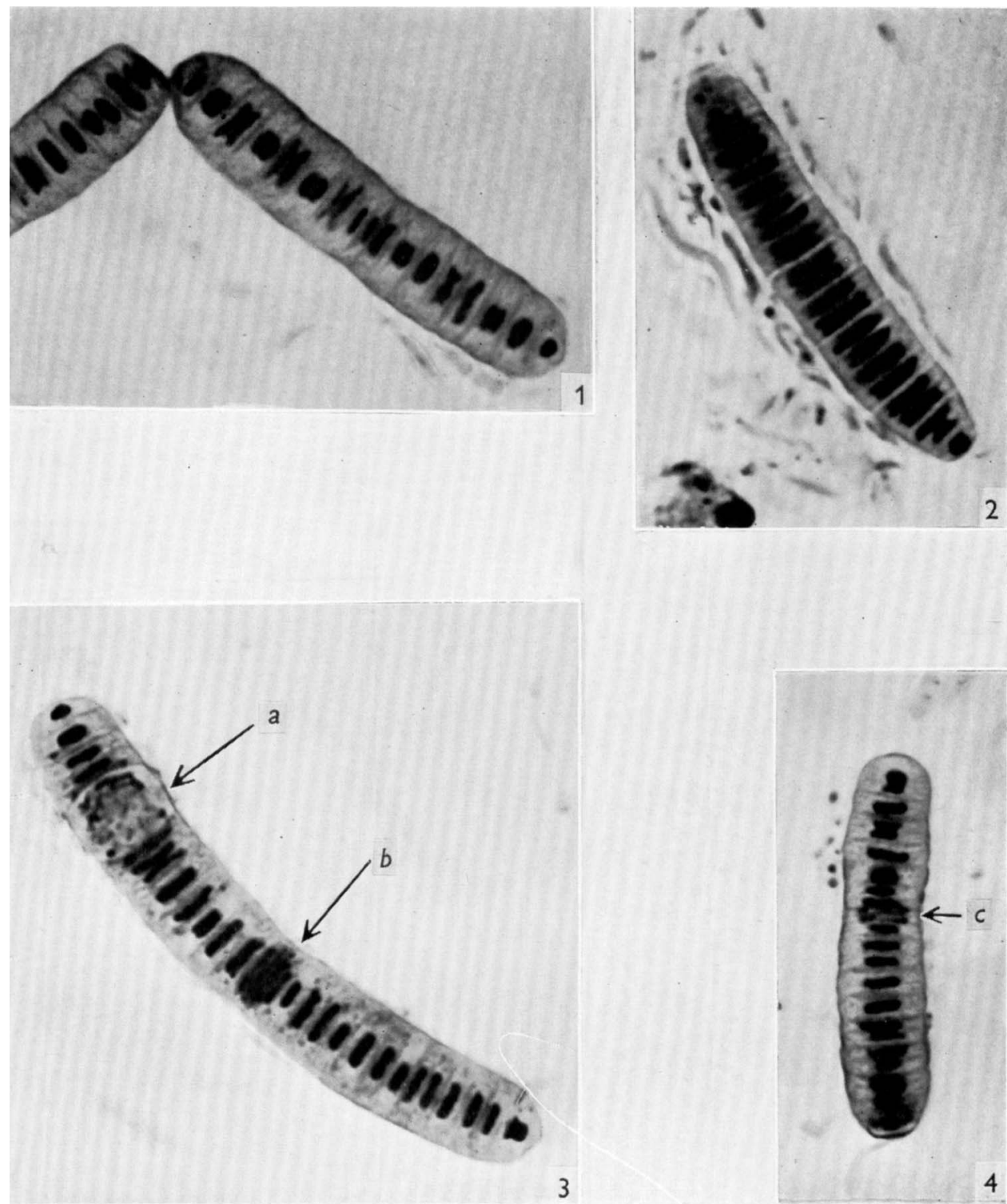

A. A. Tuffery-Nuclear structures of O. guillielimondi. Plate 1 